\title{
Bacterial Profile, Multi-Drug Resistance and Seasonality Following Lower Limb Orthopaedic Surgery in Tropical and Subtropical Australian Hospitals: An Epidemiological Cohort Study
}

\author{
Mark L. Vickers ${ }^{1, *}$, Emma L. Ballard ${ }^{2}$, Patrick N. A. Harris ${ }^{3}{ }^{1}$, Luke D. Knibbs ${ }^{4}$, \\ Anjali Jaiprakash ${ }^{5}$, Joel M. Dulhunty ${ }^{6}{ }^{(0)}$, Ross W. Crawford ${ }^{1}$ and Benjamin Parkinson ${ }^{7}(\mathbb{D}$ \\ 1 Biomedical Engineering and Clinical Sciences, Queensland University of Technology, Brisbane 4000, \\ Australia; r.crawford@qut.edu.au \\ 2 QIMR Berghofer Medical Research Institute, Brisbane 4006, Australia; emma.ballard@qimrberghofer.edu.au \\ 3 UQ Centre for Clinical Research, The University of Queensland, Brisbane 4006, Australia; p.harris@uq.edu.au \\ 4 School of Public Health, The University of Queensland, Brisbane 4006, Australia; 1.knibbs@uq.edu.au \\ 5 Science and Engineering Faculty, Queensland University of Technology, Brisbane 4000, Australia; \\ anjali.jaiprakash@qut.edu.au \\ 6 School of Public Health and Social Work, Queensland University of Technology, Brisbane 4006, Australia; \\ Joel.Dulhunty@health.qld.gov.au \\ 7 Department of Orthopaedics, Cairns Base Hospital, Cairns 4870, Australia; benjaminparkinson@gmail.com \\ * Correspondence: mark.vickers@uq.net.au; Tel.: +61-738-837-777
}

Received: 23 November 2019; Accepted: 15 January 2020; Published: 20 January 2020

\begin{abstract}
We aimed to describe the epidemiology, multi-drug resistance and seasonal distribution of bacteria cultured within 12 months following lower limb orthopaedic surgery in tropical and subtropical Australian hospitals between 2010 and 2017. We collected data from four tropical and two subtropical hospitals. Categorical variables were examined using the Pearson Chi-squared test or Fisher's Exact test, and continuous variables with the Student t-test or Mann-Whitney U test. A Poisson regression model was used to examine the relationship between season, weather and the incidence of Staphylococcus and nonfermentative species. We found that at tropical sites, nonfermenters (Pseudomonas aeruginosa and Acinetobacter baumannii) were more common ( $28.7 \% \mathrm{vs.}$ $21.6 \%, p=0.018$ ), and patients were more likely to culture multi-drug-resistant (MDR) nonfermenters $(11.4 \%$ vs. $1.3 \%, p=0.009)$ and MDR Staphylococcus aureus (35.9\% vs. $24.6 \%, p=0.006)$. At tropical sites, patients were more likely to be younger (65.9 years vs. $72.0, p=<0.001$ ), male ( $57.7 \%$ vs. $47.8 \%$, $p=0.005)$, having knee surgery $(45.3 \%$ vs. $34.5 \%, p=0.002)$ and undergoing primary procedures $(85.0 \%$ vs. $73.0 \%, p=<0.001)$. Species were similar between seasons in both tropical and subtropical hospitals. Overall, we found that following lower limb orthopaedic surgery in tropical compared with subtropical Australia, patients were more likely to culture nonfermenters and some MDR species.
\end{abstract}

Keywords: orthopaedics; multiple drug resistance; bacteria; antibacterial agents; epidemiology

\section{Introduction}

It is well known that Gram-positive organisms including Staphylococcus aureus and coagulase-negative staphylococci (CONS) are the most frequently identified pathogens complicating orthopaedic surgery [1]. However, Gram-negatives including Pseudomonas aeruginosa, Klebsiella pneumoniae and Acinetobacter baumannii are also relatively common, involved in up to $17 \%$ of infections [1-3]. Following the recent era of widespread antibiotic use, a number of bacteria have come to exhibit high levels of antibiotic resistance, and it is increasingly recognized that infection with a 
multi-drug-resistant (MDR) organism increases morbidity, mortality and healthcare costs [4-6]. While local bacterial profile and resistance rates are influenced by a range of factors, including antibiotic use and host immune status, several orthopaedic studies have also suggested that environment and season influence bacterial pathogenicity due to changes in human activity and weather [7-13]. At higher temperatures, it has been shown that there are increased levels of bacteria present in some anatomical locations, potentially due to changes in skin moisture and $\mathrm{pH}[13,14]$.

Though conditions within the orthopaedic operating theatre are controlled, patients are soon discharged to the community, where weather conditions may be ideal for bacterial growth. In Australia, hospitals in tropical regions experience annual cycles of high temperature and high relative humidity. In their study of national joint replacement registry data, Parkinson et al. recently identified higher early revision rates for prosthetic joint infection (PJI) in tropical vs. subtropical Australian hospitals [9]. At their tropical Australian institution, Armit et al. also suggested that relative humidity played an important role in postoperative infection rates [15]. To our knowledge, there are no prior studies that describe the epidemiology or multi-drug resistance of bacteria following orthopaedic surgery in a tropical region $[13,16]$. A better understanding of the bacteria driving regional orthopaedic infections will enhance surveillance, inform antibiotic selection and assist infection control.

Hence, the objectives of this study were to describe the bacterial species cultured from swabs taken following hip and knee surgery between 2010 and 2017 in northern Australian hospitals; identify differences in bacterial species and resistance rates between tropical and subtropical locations; and describe the prevalence of bacterial species by season.

\section{Materials and Methods}

\subsection{Hospital and Patient Data}

We conducted a retrospective, multisite, cohort study. Four tropical and two subtropical Australian public hospitals located across four geographic regions were included. These sites were chosen because they were major orthopaedic centres for the included regions. Sites were defined as tropical or subtropical based on the Köppen climate classification system used by the Australian Bureau of Meteorology [17]. Though within a Köppen subtropical region, we defined Site D as tropical because it experienced similar humidity and temperature to tropical sites, was north of the Tropic of Capricorn (Latitude $23.43673^{\circ}$ ) and bordered a tropical zone. A map showing climate regions within Australia and the location of included sites is shown in Figure 1. 


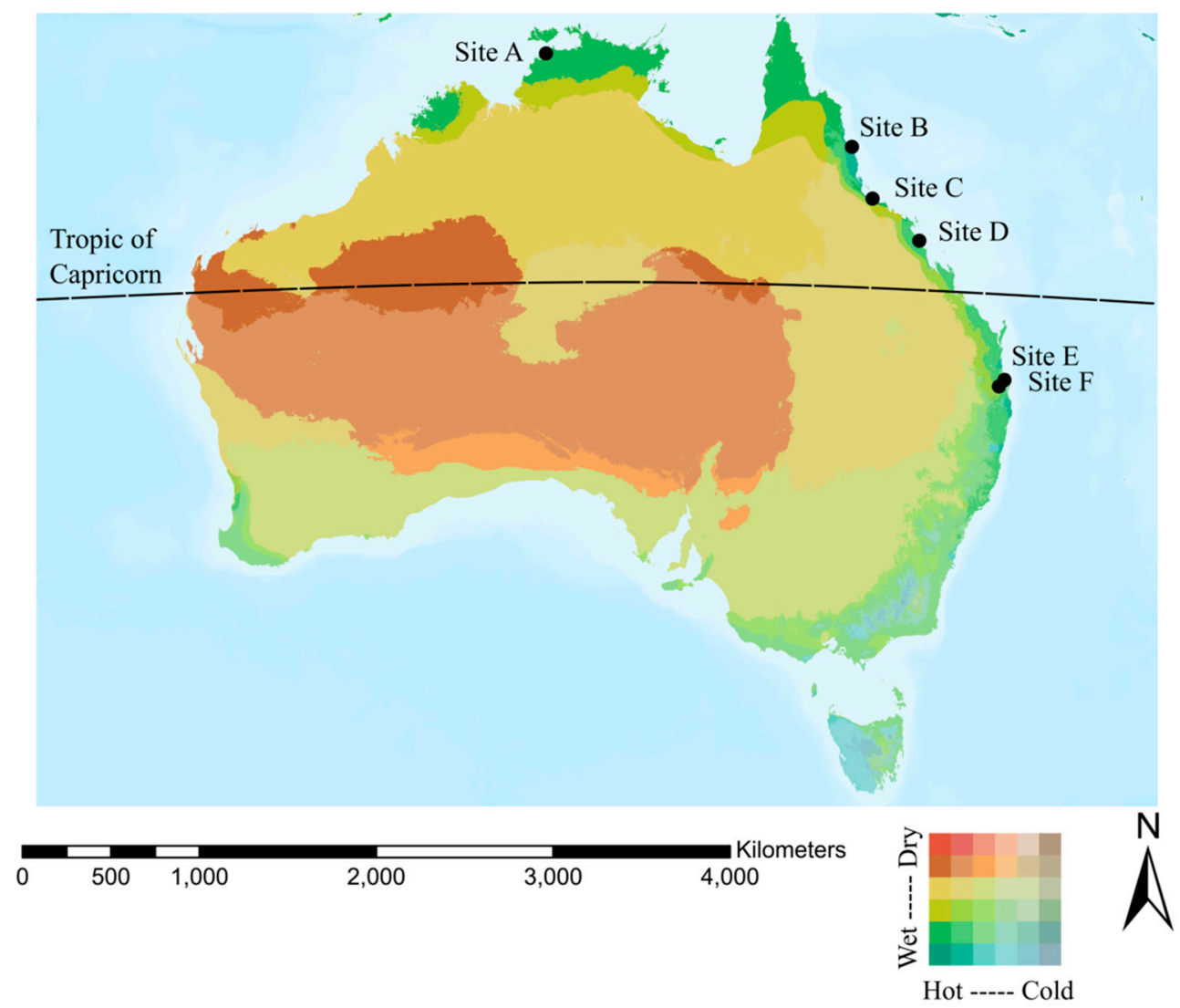

Figure 1. Climate map of Australia showing hospital site locations. Climate layer consists of 37 bioclimate zones derived from a combination of moisture and temperature variables, source: Esri, HERE, Garmin, FAO, NOAA, USGS, (C) OpenStreetMap contributors and the GIS User Community, Source: Esri; Metzger, et.al. 2012.

We included all patients over the age of 18 who underwent any lower limb orthopaedic procedure between 1 January 2010 and 30 June 2017 and who had a positive wound swab cultured. We collected data on age, gender, procedure type, procedure dates and admission dates. For patients who received multiple procedures across the study period, we considered each procedure within its hospital admission as a discrete event, and where multiple procedures occurred during a single admission, we collapsed these into a single event. Patients were identified by searching hospital inpatient databases using the International Classification of Diseases (ICD) coding system. Our search included 78 unique ICD lower limb procedure codes. Traumatic open fractures were not included. A full list of included ICD codes and procedure descriptions are available in Appendix A.

Ethics approval for five hospitals in the state of Queensland was granted by the Townsville Hospital and Health Service Human Research and Ethics Committee (HREC/17/QTHS/55). Ethics approval for one hospital in the Northern Territory was granted by the Human Research and Ethics Committee of the Northern Territory Department of Health and Menzies School of Health Research (2017-2992).

\subsection{Microbiological Data}

Bacteria were included if collected from patients on the day of surgery or any day within the following 12 months. We collected data on species, collection date, antibiotic resistance and body site. Where a patient cultured the same species on more than one occasion, we recorded that species only once using the earliest collection date after the orthopaedic procedure. Swab results were obtained from the relevant pathology Laboratory Information System (AUSLAB, Citadel Health Pty Ltd., Melbourne, Australia; Labtrak, Intersystems, Cambridge, MA, USA). 
We grouped Gram-positive bacteria into four categories: S. aureus, Coagulase negative staphylococci (CONS) (which included Staphylococcus epidermidis, Staphylococcus capitis and Staphylococcus lugdunensis), Enterococcus spp. and Streptococcus spp. For enterococci, we included Enterococcus faecalis and Enterococcus faecium. Our Streptococcus group comprised the following: beta-haemolytic streptococci (Lancefield group A, group B, group C and group G), Peptostreptococcus, Streptococcus pneumoniae, viridans group and anginosus-constellatus group.

Gram-negative bacteria were grouped into Enterobacteriaceae, and Gram-negative nonfermentative spp. Enterobacteriaceae included Morganella morganii, Proteus mirabilis, Escherichia coli, Klebsiella spp., Serratia marcescens and Enterobacter cloacae. Gram-negative nonfermenters included P. aeruginosa and A. baumannii.

We defined superficial and deep infection based on the time component described in the Centers for Disease Control guidelines, which limits superficial surgical site infection (SSI) as occurring within 30 days following an operation and deep SSI as occurring from 30 to 90 days [18]. We also included a late infection category, defined as occurring from 90 to 365 days. We limited this to one year in an attempt to control for potential patient exposure to multiple seasonal weather cycles, other surgery, illness or travel. Time of isolation of pathogen from surgery was used as a proxy for infection only, and patient charts were not reviewed to confirm clinician-diagnosed infection. Swab collection site was categorized as hip, knee, other or not specified. We included only bacteria obtained from superficial wounds, orthopaedic surgical wounds and a joint sinus or during orthopaedic procedures.

Multi-drug resistance was defined as nonsusceptibility to at least one agent in three or more classes, as described by the joint initiative on standard definitions for acquired resistance [19]. We automatically assigned Methicillin-resistant S. aureus (MRSA) and Vancomycin-resistant enterococci (VRE) as MDR.

\subsection{Meteorological Data}

For each site, we collected data across the study period for temperature, relative humidity, dew point and rainfall. Dew point is the temperature at which water vapour condenses into liquid and is useful because it is formulated with consideration of atmospheric pressure, temperature and relative humidity. Multiple weather stations within a $25 \mathrm{~km}$ radius of each hospital were used to calculate regional conditions for the hospital catchment.

\subsection{Statistical Analysis}

SPSS (Version 25) and R (Version 3.6.0) were used for statistical analysis. Categorical variables were examined using the Pearson Chi-squared test and Fisher's Exact test where more than $20 \%$ of the expected values were less than 5 . Continuous variables were examined using the Student $t$-test or Mann-Whitney U test where data were not normally distributed.

The prevalence of bacterial species across the four seasons was compared using the Pearson Chi-squared test or Fisher's exact test. To assess the relationship between weather factors and bacterial incidence, a Poisson regression model was used to examine Staphylococcus and nonfermentative species separately. Count data aggregated by month and year were examined. As hospital size population numbers were inherently different between tropical and subtropical locations, models were run separately for each location and adjusted for season and weather factors (temperature, dew point, relative humidity and rainfall). Interaction terms were not included in the final models. Weather on the date of surgery was examined with separate models for average and highest value within the month. A natural cubic spline with 7 degrees of freedom was used to explore long-term trends, but was not included in the final models presented here, as the results were not significant. 


\section{Results}

\subsection{Meteorological Factors, Patient and Swab Characteristics}

Tropical regions of Australia experience an annual "wet season" between November and April, which is characterised by high humidity, tropical storms and monsoonal rain. Subtropical regions of Australia do not experience this weather pattern. We found significant differences between tropical and subtropical weather. The average daily dew point for tropical sites was higher than for subtropical sites $\left(19.3^{\circ} \mathrm{C} \pm 4.5\right.$ vs. $\left.14.6{ }^{\circ} \mathrm{C} \pm 4.8\right)$. Average daily relative humidity was also higher for tropical regions $(73.7 \% \pm 10.4 \%$ vs. $69.3 \% \pm 10.0 \%)$, as was average temperature $\left(25.3^{\circ} \mathrm{C} \pm 3.5\right.$ vs. $21.0{ }^{\circ} \mathrm{C} \pm$ 4.0). Though timing of rainfall throughout the year differed, we found that the median rainfall was similar between locations with a median of $0.0 \mathrm{~mm}$ (interquartile range (IQR), $0.0-2.5)$ for tropical sites and $0.1 \mathrm{~mm}$ (IQR, 0.0-1.8) for subtropical sites.

We collected data on 19,107 discrete admissions involving 16,176 patients. A total of 867 (4.5\%) admissions involving 841 (5.2\%) patients produced a culture-positive swab in the 12 months following lower limb orthopaedic surgery. Of the 841 culture-positive patients, $817(97.1 \%)$ had one procedure during their admission, while $22(2.6 \%)$ had two procedures and two $(0.2 \%)$ patients underwent three procedures. Details of positive swab status per site are included in Appendix B.

There was statistically significant variation in patient and swab characteristics between tropical and subtropical sites. At tropical sites, patients were younger, with a mean age at time of procedure of 65.9 years (standard deviation (SD), 16.9) vs. subtropical at 72 years (SD, 13.8, $p=<0.001$ ). At tropical sites, patients were more likely to be male (57.7\% vs. $47.8 \%, p=0.005)$. At tropical sites, a greater proportion of surgeries were related to the knee $(45.3 \%)$ vs. subtropical $(34.5 \%, p=0.002)$ and patients were also more likely to be undergoing primary rather than revision procedures $(85.0 \% \mathrm{vs}$. $73.0 \%, p=<0.001)$. A full description of significant characteristics by tropical and subtropical location is shown Table 1. 
Table 1. Differences between tropical versus subtropical hospitals for patient characteristics and bacteria cultured in the 12 months following lower limb orthopaedic procedures.

\begin{tabular}{|c|c|c|c|c|c|}
\hline Characteristic & Sub-Category & Total $(n=867)$ & $\begin{array}{l}\text { Tropical } \\
(n=519)\end{array}$ & $\begin{array}{l}\text { Sub-Tropical } \\
\quad(n=348)\end{array}$ & $p$ \\
\hline \multicolumn{2}{|c|}{ Age at procedure } & $68.3(16.0)$ & $65.9(16.9)$ & $72.0(13.8)$ & $<0.001$ \\
\hline \multirow{2}{*}{ Gender $^{1}$} & Female & $389(46.3 \%)$ & $213(42.3 \%)$ & $176(52.2 \%)$ & \multirow{2}{*}{0.005} \\
\hline & Male & $452(53.7 \%)$ & $291(57.7 \%)$ & $161(47.8 \%)$ & \\
\hline \multirow{2}{*}{ Surgical site } & Hip & $512(59.1 \%)$ & $284(54.7 \%)$ & $228(65.5 \%)$ & \multirow{2}{*}{0.002} \\
\hline & Knee & $355(40.9 \%)$ & $235(45.3 \%)$ & $120(34.5 \%)$ & \\
\hline \multirow{2}{*}{ Procedure type } & Primary & $695(80.2 \%)$ & $441(85.0 \%)$ & $254(73.0 \%)$ & \multirow{2}{*}{$<0.001$} \\
\hline & Revision & $172(19.8 \%)$ & $78(15.0 \%)$ & $94(27.0 \%)$ & \\
\hline $\begin{array}{l}\text { Polymicrobial } \\
\text { swab }\end{array}$ & & $180(20.8 \%)$ & $119(22.9 \%)$ & $61(17.5 \%)$ & 0.055 \\
\hline $\begin{array}{c}\text { Number of } \\
\text { procedures during } \\
\text { admission (median } \\
(\mathrm{IQR}))\end{array}$ & & $1(1-1)$ & $1(1-1)$ & $1(1-1)$ & 0.50 \\
\hline \multirow[b]{2}{*}{ MDR status } & MDR S. aureus & $166(31.5 \%)$ & $115(35.9 \%)$ & $54(24.6 \%)$ & 0.006 \\
\hline & $\begin{array}{l}\text { MDR Nonfermenters } \\
\text { (P. aeruginosa and } \\
\text { A. baumannii) }\end{array}$ & $18(8.0 \%)$ & $17(11.4 \%)$ & $1(1.3 \%)$ & 0.009 \\
\hline \multirow[b]{2}{*}{ Organism count } & Enterobacteriaceae & $129(14.9 \%)$ & $67(12.9 \%)$ & $62(17.8 \%)$ & 0.047 \\
\hline & $\begin{array}{c}\text { Nonfermenters }(P . \\
\text { aeruginosa \& } \\
\text { A. baumannii) }\end{array}$ & $224(25.8 \%)$ & $149(28.7 \%)$ & $75(21.6 \%)$ & 0.018 \\
\hline \multirow{3}{*}{$\begin{array}{l}\text { Swab collection for } \\
\text { Staphylococcus }(n \\
=527)\end{array}$} & Superficial $<30$ days & $236(44.8 \%)$ & $126(39.4 \%)$ & $110(53.1 \%)$ & \multirow{3}{*}{0.004} \\
\hline & Deep 30-90 days & $131(24.9 \%)$ & $82(25.6 \%)$ & $49(23.7 \%)$ & \\
\hline & Late $90-365$ days & $160(30.4 \%)$ & $112(35.0 \%)$ & $48(23.3 \%)$ & \\
\hline \multirow{4}{*}{$\begin{array}{l}\text { Enterobacteriaceae } \\
\text { swab site }(n=129)\end{array}$} & Hip & $61(47.3 \%)$ & $25(37.3 \%)$ & $36(58.1 \%)$ & \multirow{4}{*}{0.038} \\
\hline & Knee & $41(31.8 \%)$ & $26(38.8 \%)$ & $15(24.2 \%)$ & \\
\hline & Other body site & $10(7.8 \%)$ & $8(11.9 \%)$ & $2(3.2 \%)$ & \\
\hline & Not specified & $17(13.2 \%)$ & $8(11.9 \%)$ & $9(14.5 \%)$ & \\
\hline
\end{tabular}

${ }^{1}$ Calculated using person units. IQR, interquartile range; MDR, multi-drug-resistant.

\subsection{Bacterial Characteristics}

A total of 867 positive bacterial swabs were identified. The majority of bacteria cultured were Gram-positive $(715,82.5 \%)$. The most common pathogen overall was S. aureus $(527,60.8 \%)$, followed by Nonfermenters $(224,25.8 \%)$ and Enterobacteriaceae spp. (129, 14.9\%). MDR status was identified in $66.0 \%$ of CONS, $38.8 \%$ of Enterobacteriaceae, $37.3 \%$ of Enterococcus spp. and $31.5 \%$ of S. aureus. Patients who underwent surgery at tropical sites were more likely to culture MDR S. aureus (35.9\%) vs. those at subtropical locations $(24.9 \%, p=0.006)$. Further details of antimicrobial sensitivity rates for MDR bacteria are shown in Table 2 . We also found that $S$. aureus was more commonly identified as a late infective pathogen at tropical sites $(35.0 \%)$ vs. subtropical sites $(23.2 \%, p=0.004)$. Overall, we found that Enterobacteriaceae were less common at tropical sites (12.9\% vs. $17.8 \%, p=0.047)$, and there was also a significant difference in the body region being swabbed, with a greater proportion of hip swabs culturing Enterobacteriaceae at subtropical sites $(p=0.038)$. There was a higher likelihood of culturing A. baumannii or P. aeruginosa (28.7\%) at tropical sites vs. subtropical (21.6\%, $p=0.018)$, and MDR nonfermenters tended to be associated with tropical locations $(11.4 \%$ vs. $1.3 \%, p=0.009)$. We also note that Streptococcus spp. differed by location, though bacterial numbers were low. Though not statistically significant, we note that polymicrobial swab status was more likely in tropical locations $(22.9 \%$ vs. $17.5 \%, p=0.055)$. Full details of bacterial species by tropical and subtropical location are 
shown in Appendix C. No significant differences were observed between seasons or months for any of the bacterial species at tropical or subtropical locations (Appendices D and E). Poisson regression models of Staphylococcus spp. and nonfermenters by season and month showed no evidence of seasonal spikes in bacterial count. Average and maximum values of meteorological variables were included as main effects, but none were significant in any of the models examined and thus, are not shown.

Table 2. Antibiotic susceptibilities of MDR bacteria cultured from patients in the 12 months following orthopaedic lower limb surgery in Australian tropical and subtropical hospitals.

\begin{tabular}{|c|c|c|}
\hline Organism/Organism Group & Antibiotic ${ }^{1}$ & $\begin{array}{c}\text { Percentage of MDR Isolates } \\
\text { Susceptible }\end{array}$ \\
\hline \multirow{4}{*}{ MDR S. aureus ${ }^{2}(n=166)$} & Flucloxacillin or Cephazolin & $30 \%$ \\
\hline & Erythromycin or Clindamycin & $50 \%$ \\
\hline & Trimethoprim-Sulphamethoxazole & $79 \%$ \\
\hline & Vancomycin & $99 \%$ \\
\hline \multirow{4}{*}{ MDR CONS $(n=31)$} & Flucloxacillin or Cephazolin & $10 \%$ \\
\hline & Erythromycin or Clindamycin & $16 \%$ \\
\hline & Trimethoprim-Sulphamethoxazole & $48 \%$ \\
\hline & Vancomycin & $100 \%$ \\
\hline \multirow{3}{*}{ MDR Enterococci $(n=22)$} & Ampicillin & $73 \%$ \\
\hline & Vancomycin & $77 \%$ \\
\hline & Teicoplanin & $95 \%$ \\
\hline \multirow{9}{*}{ MDR Enterobacteriaceae $(n=50)$} & Ampicillin & $0 \%$ \\
\hline & Amoxicillin-Clavulanic Acid & $4 \%$ \\
\hline & Cephazolin & $4 \%$ \\
\hline & Trimethoprim-Sulphamethoxazole & $82 \%$ \\
\hline & Ceftriaxone & $86 \%$ \\
\hline & Piperacillin-Tazobactam & $88 \%$ \\
\hline & Gentamicin & $90 \%$ \\
\hline & Ciprofloxacin & $90 \%$ \\
\hline & Meropenem & $100 \%$ \\
\hline \multirow{5}{*}{$\begin{array}{l}\text { MDR } P \text {. aeruginosa and } A . \\
\text { baumannii }(n=18)\end{array}$} & Ceftazidime & $44 \%$ \\
\hline & Ciprofloxacin & $50 \%$ \\
\hline & Piperacillin-Tazobactam & $61 \%$ \\
\hline & Gentamicin & $67 \%$ \\
\hline & Meropenem & $67 \%$ \\
\hline
\end{tabular}

Streptococci $(n=0)$

${ }^{1}$ Only antibiotics commonly used and of interest are listed. ${ }^{2}$ Resistance profile not available for four MRSA data points. CONS, coagulase-negative staphylococci.

\section{Discussion}

Our study aimed to describe the epidemiology, resistance rates and seasonal distribution of bacteria cultured following lower limb orthopaedic surgery in tropical and subtropical northern Australian hospitals between 2010 and 2017. We identified several statistically significant differences between tropical and subtropical sites. At tropical sites, we found that nonfermenters (P. aeruginosa and A. baumannii) were more common and that patients were more likely to culture MDR nonfermenters and MDR S. aureus. At tropical sites, we also found that patients with culture-positive swab collection were more likely to be younger, male, had undergone knee surgery and have had primary procedures. These differences likely reflect variations between regional and metropolitan orthopaedic practice and the importance of understanding the regional antibiogram. Though weather factors differed between tropical and subtropical regions, there was no evidence that weather influenced bacterial count and no evidence of seasonality at either tropical or subtropical sites.

The frequency of $P$. aeruginosa and A. baumannii identified in our study was higher than elsewhere in the literature. In their cohort of orthopaedic trauma patients in Brazil, Tuon et al. found that 
P. aeruginosa made up $11.6 \%$ of bacteria cultured from surgical site infections, while Dudareva et al. in the United Kingdom and Ma et al. in China found that nonfermenters comprised $6.5 \%$ and $7.6 \%$ of cultured organisms from chronic osteomyelitis patients, respectively [20-22]. In Taiwan, Wang et al. also identified lower rates of $P$. aeruginosa, which made up just $2.8 \%$ of pathogens causing prosthetic joint infection [23]. Though the mechanisms are unclear, in our study, the higher frequency of nonfermenters identified at tropical vs. sub-tropical sites likely reflects a predilection of these pathogens for included regions, and the complexity of niches may mean that, even within tropical environments, there are regions of varying suitability for these organisms. Meteorological differences between tropical and subtropical regions may be driving the differences in pathogen profile between regions in our study. We also found that MDR nonfermenters and MDR S. aureus rates were higher at tropical sites vs. subtropical. Reported cases of MDR nonfermenters in the orthopaedic literature are too low to be comparable; however, we note that our rates of MDR S. aureus are consistent with other studies [20,21,23-26]. In their assessment of pathogens cultured from surgical site infections following joint arthroplasty and spinal fusions, Norton et al. found that $33 \%$ of S. aureus was methicillin-resistant and similarly, Dudareva et al. identified that $22.5 \%$ of $S$. aureus species cultured from chronic osteomyelitis patients in the United Kingdom were MDR [20,24]. MDR S. aureus and nonfermenters may be more endemic in the Australian tropical healthcare system for a variety of reasons. The influence of tropical weather on the skin microbiome, local hospital and community antibiotic use, human travel, agriculture and regional wastewater management strategies likely all contribute to the pathogenic potential of these MDR bacteria in the region studied [6].

We found that at tropical sites, patients with positive swabs following surgery were more likely to be younger, male, had undergone knee surgery and have had primary procedures. Age and gender have been well described in the literature as risk factors for infection following orthopaedic surgery, and it is also known from national joint replacement registry data that knee replacements pose a higher risk than for hips [27-30]. We note that both subtropical sites included in our study are located within the same metropolitan city, while the four tropical sites are regional and remote with substantially lower population densities. It is likely that the differences in patient and surgery characteristics identified in our study reflect trends in metropolitan versus regional orthopaedic practice.

We did not identify any evidence of seasonal spikes in microbiological samples positive for potentially pathogenic bacteria or any relationship between weather and frequency. This is in contrast to prior studies that have demonstrated an increased incidence of orthopaedic infections at certain times of the year $[7,9,11,31]$. For instance, in their United States study, Anthony et al. showed an increased risk of 30 day readmission for SSI following lower limb arthroplasty in the summer months, and following spinal surgery at their institution. Gruskay et al. also identified an increased incidence of wound infection during the summer and autumn [11,31]. Our study suggests that in tropical and subtropical Australia there is either no seasonal spike in infection rates or this is too small to be appreciable. This is supported by our recent meta-analysis, which demonstrated from cumulative data only a marginally increased risk of postoperative infection following orthopaedic surgery in the warmer months [32]. While prior studies have suggested that warmer, wetter conditions lead to increased infection risk, we believe that the main effect relates to a change in pathogen profile. It is likely that in tropical conditions, different pathogens predominate compared with temperate climates and that any increased risk of infection is due to inadequate antimicrobial prophylaxis for these species. In north-eastern Australia there does not appear to be, however, a seasonal increase in microbiologial sample counts due to this difference in pathogen profile.

Our study had several limitations. Firstly, we used the time between surgery and pathogen culture as a proxy for defining infection type. This is only one component of the CDC definition for surgical site infections, and individual charts were not reviewed to confirm infection status, as such it is likely that a number of our bacterial data points were contaminants only. We attempted to control for this by only including bacteria labelled as obtained from superficial wounds, orthopaedic surgical sites, joint sinuses and intraoperatively. We also included swab data from both the day of surgery and 
on any day in the 12 months following. While this was intended to capture potential infections which occur both at the time of surgery and possibly days or weeks later, we note that this data collection method may have led to detection bias. In addition, clinicians frequently treat orthopaedic surgical site infections empirically without swab collection, so it is likely that our data represents only a subset of postoperative orthopaedic pathogens. Similarly, our study included only public patients, so our findings may not be broadly transferable. Finally, our research question may have better been served by comparing temperate sites with tropical.

\section{Conclusions}

At tropical vs. subtropical Australian hospitals between 2010 and 2017, patients who cultured bacteria in the 12 months following any lower limb orthopaedic surgery were more likely to culture nonfermenters (P. aeruginosa and A. baumannii), MDR nonfermenters and MDR S. aureus. These patients were also more likely to be younger males undergoing knee surgery and having primary procedures. In contrast to prior studies, we identified no increase in positive swab status at warmer times of the year.

Author Contributions: Data curation, M.L.V. and B.P.; formal analysis, M.L.V. and E.L.B.; investigation, M.L.V. and E.L.B.; methodology, M.L.V., E.L.B., P.N.A.H., L.D.K., A.J., J.M.D., R.W.C., and B.P.; project administration, M.L.V. and B.P.; writing—original draft, M.L.V.; writing—review and editing, M.L.V., E.L.B., P.N.A.H., L.D.K., A.J., J.M.D., R.W.C. and B.P.; supervision, A.J., J.M.D., R.W.C. and B.P., conceptualization, J.M.D. and B.P. All authors have read and agreed to the published version of the manuscript.

Funding: This research received no external funding.

Acknowledgments: Andrea Grant, (The ORIQL, The Orthopaedic Research Institute of QLD) who provided significant contribution to protocol drafting and the ethics application process. Associate Professor Rob Baird, (Department of Health, Northern Territory Government) who provided significant assistance with access to data within the Northern Territory.

Conflicts of Interest: The authors declare no conflict of interest.

\section{Appendix A}

List of All Included Orthopaedic Procedures

\begin{tabular}{ccl}
\hline Number & ICD Code & Procedure Description \\
\hline 1. & $148850393-00$ & Bone graft to pelvis \\
2. & $148848200-00$ & Bone graft to femur \\
3. & $148848203-00$ & Bone graft to femur with internal fixation \\
4. & $148947522-00$ & Hemi-arthroplasty of femur (Austin Moore) \\
5. & $148949312-00$ & Excision arthroplasty of hip \\
6. & $148949315-00$ & Partial arthroplasty of hip \\
7. & $148990607-00$ & Resurfacing of hip, unilateral \\
8. & $148990607-01$ & Resurfacing of hip, bilateral \\
9. & $148949318-00$ & Total arthroplasty of hip, unilateral \\
10. & $148949319-00$ & Total arthroplasty of hip, bilateral \\
11. & $149050121-00$ & Transplantation of iliopsoas tendon to greater trochanter \\
12. & $149050387-00$ & Transfer of iliopsoas tendon to greater trochanter \\
13. & $149050387-01$ & Transfer of abdominal musculature to greater trochanter \\
14. & $149050387-02$ & Transfer of adductors to ischium \\
15. & $149149300-00$ & Arthrodesis of sacro-iliac joint \\
16. & $149149306-00$ & Arthrodesis of hip \\
17. & $149148500-00$ & Epiphysiodesis of femur \\
18. & $149148506-00$ & Epiphysiodesis of femur and tibia and fibula \\
19. & $149150224-09$ & En bloc resection of lesion of soft tissue involving penis (prosthesis) \\
\hline
\end{tabular}




\begin{tabular}{|c|c|c|}
\hline Number & ICD Code & Procedure Description \\
\hline 20. & $149150224-10$ & En bloc resection of lesion of soft tissue involving penis (allograft) \\
\hline 21. & $149150224-11$ & En bloc resection of lesion of soft tissue involving penis (autograft) \\
\hline 22. & $149196225-00$ & Arthroscopic repair of hip \\
\hline 23. & $149190552-00$ & Other repair of hip \\
\hline 24. & $151149561-02$ & $\begin{array}{l}\text { Arthroscopic removal of loose body of knee with } \\
\text { debridement/osteoplasty/chondroplasty }\end{array}$ \\
\hline 25. & $151149562-02$ & $\begin{array}{l}\text { Arthroscopic removal of loose body of knee with } \\
\text { chondroplasty/drilling/implant }\end{array}$ \\
\hline 26. & 1512 49509-01 & Arthrodesis of knee \\
\hline 27. & $151249512-00$ & Arthrodesis of knee with removal of prosthesis \\
\hline 28. & $151348206-00$ & Bone graft to tibia \\
\hline 29. & 1513 48209-00 & Bone graft to tibia with internal fixation \\
\hline 30. & $151449561-00$ & $\begin{array}{l}\text { Arthroscopic lateral release of knee with } \\
\text { debridement/osteoplasty/chondroplasty }\end{array}$ \\
\hline 31. & $151449562-00$ & Arthroscopic lateral release of knee with chondroplasty/drilling/implant \\
\hline 32. & $151550411-00$ & Resection of distal femur and proximal tibia with knee fusion \\
\hline 33. & $151550414-00$ & $\begin{array}{l}\text { Resection of distal femur and proximal tibia with knee fusion and } \\
\text { rotationplasty }\end{array}$ \\
\hline 34. & $151650357-00$ & Transfer of rectus femoris hamstring tendon \\
\hline 35. & $151650357-01$ & Transfer of medial hamstring tendon \\
\hline 36. & $151650357-02$ & Transfer of lateral hamstring tendon \\
\hline 37. & $151650360-00$ & Transfer of combined medial and lateral hamstring tendon \\
\hline 38. & $151649503-03$ & Transfer of tendon or ligament of knee (not elsewhere defined) \\
\hline 39. & $151650423-00$ & Transfer of fibula to tibia with external fixation \\
\hline 40. & $151749561-01$ & $\begin{array}{l}\text { Arthroscopic menisectomy of knee with debridement, osteoplasty or } \\
\text { chondroplasty }\end{array}$ \\
\hline 41. & $151749562-01$ & Arthroscopic menisectomy of knee with chondroplasty/drilling/implant \\
\hline 42. & $151849517-00$ & Hemi-arthroplasty of knee \\
\hline 43. & $151849518-00$ & Total arthroplasty of knee, unilateral \\
\hline 44. & 1518 49519-00 & Total arthroplasty of knee, bilateral \\
\hline 45. & $151849534-01$ & Total replacement arthroplasty of patellofemoral joint of knee \\
\hline 46. & $151949521-00$ & Total arthroplasty of knee with bone graft to femur, unilateral \\
\hline 47. & $151949521-01$ & Total arthroplasty of knee with bone graft to femur, bilateral \\
\hline 48. & $151949521-02$ & Total arthroplasty of knee with bone graft to tibia, unilateral \\
\hline 49. & $151949521-03$ & Total arthroplasty of knee with bone graft to tibia, bilateral \\
\hline 50. & $151949524-00$ & Total arthroplasty of knee with bone graft to femur and tibia, unilateral \\
\hline 51. & $151949524-01$ & Total arthroplasty of knee with bone graft to femur and tibia, bilateral \\
\hline 52. & $149249346-00$ & Revision of partial arthroplasty of hip \\
\hline 53. & 1492 49324-00 & Revision of total arthroplasty of hip \\
\hline 54. & 1492 49327-00 & Revision of total arthroplasty of hip with bone graft to acetabulum \\
\hline 55. & $149249330-00$ & Revision of total arthroplasty of hip with bone graft to femur \\
\hline 56. & $149249333-00$ & $\begin{array}{l}\text { Revision of total arthroplasty of hip with bone graft to acetabulum and } \\
\text { femur }\end{array}$ \\
\hline 57. & 1492 49339-00 & $\begin{array}{l}\text { Revision of total arthroplasty of hip with anatomic specific allograft to } \\
\text { acetabulum }\end{array}$ \\
\hline 58. & $149249342-00$ & $\begin{array}{l}\text { Revision of total arthroplasty of hip with anatomic specific allograft to } \\
\text { femur }\end{array}$ \\
\hline 59. & $149249345-00$ & $\begin{array}{l}\text { Revision of total arthroplasty of hip with anatomic specific allograft to } \\
\text { acetabulum and femur Internal }\end{array}$ \\
\hline 60. & $152147588-00$ & Fixation of intra-articular fracture of femoral condyle with repair \\
\hline
\end{tabular}




\begin{tabular}{|c|c|c|}
\hline Number & ICD Code & Procedure Description \\
\hline 61. & $152147588-01$ & $\begin{array}{l}\text { Internal fixation of intra-articular fracture of tibial articular surface of } \\
\text { knee with repair }\end{array}$ \\
\hline 62. & $152147591-00$ & $\begin{array}{l}\text { Internal fixation of intra-articular fracture of femoral condyle and tibial } \\
\text { articular surface }\end{array}$ \\
\hline 63. & 1522 49539-00 & Arthroscopic reconstruction of knee \\
\hline 64. & 1522 49539-01 & Reconstruction of knee \\
\hline 65. & $152249542-00$ & $\begin{array}{l}\text { Arthroscopic reconstruction of cruciate ligament of knee and repair } \\
\text { meniscus }\end{array}$ \\
\hline 66. & $152249542-01$ & Reconstruction of cruciate ligament of knee with repair of meniscus \\
\hline 67. & $152290611-00$ & Patellar tendon shortening \\
\hline 68. & $152290611-01$ & Patellar tendon advancement \\
\hline 69. & $152250417-00$ & $\begin{array}{l}\text { Reconstruction of knee involving transfer of fibula and tibia or repair of } \\
\text { quads }\end{array}$ \\
\hline 70. & $152349530-00$ & Revision of total arthroplasty of knee with bone graft to femur \\
\hline 71. & $152349530-01$ & Revision of total arthroplasty of knee with bone graft to tibia \\
\hline 72. & $152349533-00$ & Revision of total arthroplasty of knee with bone graft to femur and tibia \\
\hline 73. & $152349554-00$ & Revision of total arthroplasty of knee with anatomic specific allograft \\
\hline 74. & 1524 49545-00 & Revision of arthrodesis of knee \\
\hline 75. & 1524 49548-00 & Revision of patellofemoral stabilisation of knee \\
\hline 76. & 1524 49551-00 & Revision of reconstructive surgery of knee \\
\hline 77. & 1524 49527-00 & Revision of total arthroplasty of knee \\
\hline 78. & $152490562-00$ & Patella resurfacing \\
\hline
\end{tabular}

\section{Appendix B}

Admission, Swab and Weather Station Data by Hospital Site

\begin{tabular}{|c|c|c|c|c|c|c|}
\hline Status & Hospital & $\begin{array}{l}\text { Location } \\
\text { Latitude } \\
\text { and } \\
\text { Longitude }\end{array}$ & $\begin{array}{l}\text { Number of } \\
\text { Weather } \\
\text { Stations } \\
\text { Within } 25 \\
\text { km Radius }\end{array}$ & $\begin{array}{c}\text { Total } \\
\text { Admission } \\
\text { Events }\end{array}$ & $\begin{array}{l}\text { Admissions } \\
\text { Followed by } \\
\text { Positive } \\
\text { Swabs }\end{array}$ & Percentage \\
\hline Tropical & Site A & $\begin{array}{c}-12.354860 \\
130.882845\end{array}$ & 25 & 1107 & 71 & $6.4 \%$ \\
\hline Tropical & Site B & $\begin{array}{c}-16.912178 \\
145.768408\end{array}$ & 10 & 2818 & 149 & $5.3 \%$ \\
\hline Tropical & Site C & $\begin{array}{c}-19.320384 \\
146.762324\end{array}$ & 3 & 2937 & 202 & $6.9 \%$ \\
\hline Tropical & Site D & $\begin{array}{c}-21.145531 \\
149.155603\end{array}$ & 7 & 1767 & 97 & $5.5 \%$ \\
\hline Subtropical & Site E & $\begin{array}{c}-27.227687 \\
153.104899\end{array}$ & 13 & 2942 & 84 & $2.9 \%$ \\
\hline Subtropical & Site F & $\begin{array}{c}-27.389547 \\
153.022753\end{array}$ & 24 & 7536 & 264 & $3.5 \%$ \\
\hline
\end{tabular}




\section{Appendix C}

Profile of Bacteria Cultured Within 12 Months Following Lower Limb Orthopaedic Procedures in Australian Tropical and Subtropical Hospitals

\begin{tabular}{|c|c|c|c|c|c|}
\hline Group & Species & Total $(n=867)$ & $\begin{array}{l}\text { Tropical } \\
(n=519)\end{array}$ & $\begin{array}{l}\text { Sub-tropical } \\
\quad(n=348)\end{array}$ & $p$ \\
\hline \multirow{4}{*}{ Staphylococcus } & Total & $527(60.8 \%)$ & $320(61.7 \%)$ & $270(59.5 \%)$ & 0.52 \\
\hline & S. aureus & $426(80.8 \%)$ & $259(80.9 \%)$ & 167 (80.7\%) & \multirow{2}{*}{0.94} \\
\hline & MRSA & $101(19.2 \%)$ & $61(19.1 \%)$ & $40(19.3 \%)$ & \\
\hline & MDR S. aureus & $166(31.5 \%)$ & $115(35.9 \%)$ & $51(24.6 \%)$ & 0.006 \\
\hline \multirow{6}{*}{ CONS } & Total & $47(5.4 \%)$ & $24(4.6 \%)$ & $23(6.6 \%)$ & 0.21 \\
\hline & S. capitis & $7(14.9 \%)$ & $3(12.5 \%)$ & $4(17.4 \%)$ & \multirow{4}{*}{0.49} \\
\hline & S. epidermidis & $32(68.1 \%)$ & $18(75.0 \%)$ & $14(60.9 \%)$ & \\
\hline & S. lugdunensis & $5(10.6 \%)$ & $1(4.2 \%)$ & $4(17.4 \%)$ & \\
\hline & S. haemolyticus & $3(6.4 \%)$ & $2(8.3 \%)$ & $1(4.3 \%)$ & \\
\hline & MDR CONS & $31(66.0 \%)$ & $17(70.8 \%)$ & $14(60.9 \%)$ & 0.47 \\
\hline \multirow{4}{*}{ Enterococcus } & Total & $59(6.8 \%)$ & $32(6.2 \%)$ & $27(7.8 \%)$ & 0.36 \\
\hline & E. faecalis & $50(84.7 \%)$ & $30(93.8 \%)$ & $20(74.1 \%)$ & \multirow{2}{*}{0.066} \\
\hline & E. faecium & $9(15.3 \%)$ & $2(6.3 \%)$ & $7(25.9 \%)$ & \\
\hline & MDR Enterococcus & $22(37.3 \%)$ & $12(37.5 \%)$ & $10(37.0 \%)$ & 0.97 \\
\hline \multirow{9}{*}{ Streptococcus } & Total & $82(9.5 \%)$ & $57(11.0 \%)$ & $25(7.2 \%)$ & 0.061 \\
\hline & Group A & $41(50.0 \%)$ & $32(56.1 \%)$ & $9(36.0 \%)$ & \multirow{8}{*}{0.010} \\
\hline & Group B & $13(15.9 \%)$ & $6(10.5 \%)$ & $7(28.0 \%)$ & \\
\hline & Group C & $16(19.5 \%)$ & $14(24.6 \%)$ & $2(8.0 \%)$ & \\
\hline & Group G & $9(11.0 \%)$ & $4(7.0 \%)$ & $5(20.0 \%)$ & \\
\hline & Peptostreptococcus & $1(1.2 \%)$ & 0 & $1(4.0 \%)$ & \\
\hline & Pneumonia Group & $1(1.2 \%)$ & $1(1.8 \%)$ & 0 & \\
\hline & Viridans Group & $1(1.2 \%)$ & 0 & $1(4.0 \%)$ & \\
\hline & MDR Streptococcus & 0 & & & \\
\hline \multirow{8}{*}{ Enterobacteriaceae } & Total & $129(14.9 \%)$ & $67(12.9 \%)$ & $62(17.8 \%)$ & 0.047 \\
\hline & M. morganii & $11(8.5 \%)$ & $5(7.5 \%)$ & $6(9.7 \%)$ & \multirow{6}{*}{0.67} \\
\hline & P. mirabilis & $13(10.1 \%)$ & $7(10.4 \%)$ & $6(9.7 \%)$ & \\
\hline & E. coli & $20(15.5 \%)$ & $11(16.4 \%)$ & $9(14.5 \%)$ & \\
\hline & K. pneumoniae & $22(17.1 \%)$ & $8(11.9 \%)$ & $14(22.6 \%)$ & \\
\hline & S. marcescens & $27(20.9 \%)$ & $16(23.9 \%)$ & $11(17.7 \%)$ & \\
\hline & E. cloacae & $36(27.9 \%)$ & $20(29.9 \%)$ & $16(25.8 \%)$ & \\
\hline & MDR Enterobacteriaceae & $50(38.8 \%)$ & $26(38.8 \%)$ & $24(38.7 \%)$ & 0.99 \\
\hline \multirow{4}{*}{ Non-fermenters } & Total & $224(25.8 \%)$ & $149(28.7 \%)$ & $75(21.6 \%)$ & 0.018 \\
\hline & A. baumannii & $12(5.4 \%)$ & $11(7.4 \%)$ & $1(1.3 \%)$ & \multirow{2}{*}{0.065} \\
\hline & P. aeruginosa & $212(94.6 \%)$ & $138(92.6 \%)$ & $74(98.7 \%)$ & \\
\hline & MDR Nonfermenters & $18(8.0 \%)$ & $17(11.4 \%)$ & $1(1.3 \%)$ & 0.009 \\
\hline
\end{tabular}




\section{Appendix D}

Bacterial Species by Season in a Subtropical Location

\begin{tabular}{|c|c|c|c|c|c|c|c|}
\hline \multirow[t]{2}{*}{ Bacterial Species } & \multirow[t]{2}{*}{ Overall } & \multirow[t]{2}{*}{ Sub-Tropical } & \multicolumn{5}{|c|}{ Subtropical } \\
\hline & & & Spring & Summer & Autumn & Winter & $p$ \\
\hline & $n$ & $n$ & $n(\%)$ & $n(\%)$ & $n(\%)$ & $n(\%)$ & \\
\hline Staphylococcus & 527 & 207 & $43(60.6 \%)$ & $50(56.2 \%)$ & $62(60.2 \%)$ & $52(61.2 \%)$ & 0.91 \\
\hline MDR S. aureus & & 51 & $7(16.3 \%)$ & $12(24.0 \%)$ & $14(22.6 \%)$ & $18(34.6 \%)$ & 0.21 \\
\hline CONS & 47 & 23 & $5(7.0 \%)$ & $3(3.4 \%)$ & $12(11.7 \%)$ & $3(3.5 \%)$ & 0.069 \\
\hline MDR CONS & & 14 & $4(80.0 \%)$ & $2(66.7 \%)$ & $6(50.0 \%)$ & $2(66.7 \%)$ & 0.75 \\
\hline Enterococcus & 59 & 27 & $6(8.5 \%)$ & $4(4.5 \%)$ & $13(12.6 \%)$ & $4(4.7 \%)$ & 0.12 \\
\hline MDR Enteroccoccus & & 10 & $1(16.7 \%)$ & $2(50.0 \%)$ & $5(38.5 \%)$ & $2(50.0 \%)$ & 0.67 \\
\hline Streptococcus & 82 & 25 & $7(9.9 \%)$ & $4(4.5 \%)$ & $6(5.8 \%)$ & $8(9.4 \%)$ & 0.45 \\
\hline MDR Streptococcus & & 0 & $n / \mathrm{a}$ & $n / \mathrm{a}$ & $n / \mathrm{a}$ & $n / \mathrm{a}$ & $n / \mathrm{a}$ \\
\hline Enterobacteriaceae & 129 & 62 & $11(15.5 \%)$ & $23(25.8 \%)$ & $12(11.7 \%)$ & $16(18.8 \%)$ & 0.075 \\
\hline MDR Enterobacteriaceae & & 24 & $5(45.5 \%)$ & $8(34.8 \%)$ & $8(66.7 \%)$ & $3(18.3 \%)$ & 0.072 \\
\hline Non-fermenters & 224 & 75 & $12(16.9 \%)$ & $23(25.8 \%)$ & $22(21.4 \%)$ & $18(21.2 \%)$ & 0.60 \\
\hline MDR Non-fermenters & & 1 & $1(8.3 \%)$ & $0(0.0 \%)$ & $0(0.0 \%)$ & $0(0.0 \%)$ & 0.16 \\
\hline
\end{tabular}

\section{Appendix E}

Bacterial Species by Season in a Tropical Location

\begin{tabular}{cccccccc}
\hline Bacterial Species & Overall & Tropical & \multicolumn{7}{c}{ Tropical } \\
\hline & & & Spring & Summer & Autumn & Winter & $p$ \\
\hline Staphylococcus & $n$ & $n$ & $n(\%)$ & $n(\%)$ & $n(\%)$ & $n(\%)$ & \\
MDR S. aureus & 527 & 320 & $73(60.3 \%)$ & $85(66.4 \%)$ & $96(63.6 \%)$ & $66(55.5 \%)$ & 0.32 \\
CONS & & 115 & $29(39.7 \%)$ & $26(30.6 \%)$ & $37(38.5 \%)$ & $23(34.8 \%)$ & 0.61 \\
MDR CONS & 47 & 24 & $7(5.8 \%)$ & $2(1.6 \%)$ & $8(5.3 \%)$ & $7(5.9 \%)$ & 0.30 \\
Enterococcus & \multirow{2}{*}{59} & 17 & $4(57.1 \%)$ & $1(50.0 \%)$ & $5(62.5 \%)$ & $7(100.0 \%)$ & 0.21 \\
MDR Enteroccoccus & & 32 & $10(8.3 \%)$ & $6(4.7 \%)$ & $9(6.0 \%)$ & $7(5.9 \%)$ & 0.70 \\
Streptococcus & \multirow{2}{*}{82} & 57 & $5(50.0 \%)$ & $1(16.7 \%)$ & $2(22.2 \%)$ & $4(57.1 \%)$ & 0.31 \\
MDR Streptococcus & & 0 & $n(13.2 \%)$ & $11(8.6 \%)$ & $11(7.3 \%)$ & $19(16.0 \%)$ & 0.090 \\
Enterobacteriaceae & \multirow{2}{*}{129} & 67 & $18(14.9 \%)$ & $21(16.4 \%)$ & $11(7.3 \%)$ & $17(14.3 \%)$ & 0.10 \\
MDR Enterobacteriaceae & & 26 & $7(38.9 \%)$ & $8(38.1 \%)$ & $4(36.4 \%)$ & $7(41.2 \%)$ & 1.00 \\
Nonfermenters & 224 & 149 & $39(32.2 \%)$ & $39(30.5 \%)$ & $45(29.8 \%)$ & $26(21.8 \%)$ & 0.29 \\
MDR Nonfermenters & & 17 & $5(12.8 \%)$ & $6(15.4 \%)$ & $4(8.9 \%)$ & $2(7.7 \%)$ & 0.73 \\
\hline
\end{tabular}

\section{References}

1. Moriarty, T.F.; Kuehl, R.; Coenye, T.; Metsemakers, W.J.; Morgenstern, M.; Schwarz, E.M.; Riool, M.; Zaat, S.A.J.; Khana, N.; Kates, S.L.; et al. Orthopaedic device-related infection: Current and future interventions for improved prevention and treatment. EFORT Open Rev. 2016, 1, 89-99. [CrossRef]

2. Jamei, O.; Gjoni, S.; Zenelaj, B.; Kressmann, B.; Belaieff, W.; Hannouche, D.; Uckay, I. Which Orthopaedic Patients Are Infected with Gram-negative Non-fermenting Rods? J. Bone Joint Infect. 2017, 2, 73-76. [CrossRef]

3. Martinez-Pastor, J.C.; Munoz-Mahamud, E.; Vilchez, F.; Garcia-Ramiro, S.; Bori, G.; Sierra, J.; Martinez, J.A.; Font, L.; Mensa, J.; Soriano, A. Outcome of acute prosthetic joint infections due to gram-negative bacilli treated with open debridement and retention of the prosthesis. Antimicrob. Agents Chemother. 2009, 53, 4772-4777. [CrossRef]

4. Hsieh, P.H.; Lee, M.S.; Hsu, K.Y.; Chang, Y.H.; Shih, H.N.; Ueng, S.W. Gram-negative prosthetic joint infections: Risk factors and outcome of treatment. Clin. Infect. Dis. 2009, 49, 1036-1043. [CrossRef] [PubMed]

5. Vasso, M.; Schiavone Panni, A.; De Martino, I.; Gasparini, G. Prosthetic knee infection by resistant bacteria: The worst-case scenario. Knee Surg. Sports Traumatol. Arthrosc. 2016, 24, 3140-3146. [CrossRef] [PubMed] 
6. Li, B.; Webster, T.J. Bacteria antibiotic resistance: New challenges and opportunities for implant-associated orthopedic infections. J. Orthop. Res. 2018, 36, 22-32. [CrossRef] [PubMed]

7. Kao, H.K.; Chen, M.C.; Lee, W.C.; Yang, W.E.; Chang, C.H. Seasonal Temperature and Pin Site Care Regimen Affect the Incidence of Pin Site Infection in Pediatric Supracondylar Humeral Fractures. BioMed Res. Int. 2015, 2015, 838913. [CrossRef] [PubMed]

8. Kane, P.; Chen, C.; Post, Z.; Radcliff, K.; Orozco, F.; Ong, A. Seasonality of infection rates after total joint arthroplasty. Orthopedics 2014, 37, e182-e186. [CrossRef] [PubMed]

9. Parkinson, B.; Armit, D.; McEwen, P.; Lorimer, M.; Harris, I.A. Is Climate Associated With Revision for Prosthetic Joint Infection After Primary TKA? Clin. Orthop. Relat. Res. 2018, 476, 1200-1204. [CrossRef]

10. Haws, B.E.; Braun, B.M.; Creech, T.B.; Barnard, E.R.; Miller, A.N. Is There a Seasonal Influence on Orthopaedic Surgical Wound Infection Rates? J. Surg. Orthop. Adv. 2017, 25, 172-175.

11. Anthony, C.A.; Peterson, R.A.; Polgreen, L.A.; Sewell, D.K.; Polgreen, P.M. The Seasonal Variability in Surgical Site Infections and the Association With Warmer Weather: A Population-Based Investigation. Infect. Control Hosp. Epidemiol. 2017, 38, 809-816. [CrossRef] [PubMed]

12. Durkin, M.J.; Dicks, K.V.; Baker, A.W.; Moehring, R.W.; Chen, L.F.; Sexton, D.J.; Lewis, S.S.; Anderson, D.J. Postoperative infection in spine surgery: Does the month matter? J. Neurosurg. Spine 2015, 23, 128-134. [CrossRef] [PubMed]

13. Leekha, S.; Diekema, D.J.; Perencevich, E.N. Seasonality of staphylococcal infections. Clin. Microbiol. Infect. 2012, 18, 927-933. [CrossRef] [PubMed]

14. McBride, M.E.; Duncan, W.C.; Knox, J.M. The environment and the microbial ecology of human skin. Appl. Environ. Microbiol. 1977, 33, 603-608. [CrossRef] [PubMed]

15. Armit, D.; Vickers, M.; Parr, A.; Van Rosendal, S.; Trott, N.; Gunasena, R.; Parkinson, B. Humidity a potential risk factor for prosthetic joint infection in a tropical Australian hospital. ANZ J. Surg. 2018, 88, 1298-1301. [CrossRef]

16. Fisman, D.N. Seasonality of infectious diseases. Annu. Rev. Public Health 2007, 28, 127-143. [CrossRef]

17. Australian Government, Bureau of Meteorology, Climate Classification Maps. Available online: http://www. bom.gov.au/jsp/ncc/climate_averages/climate-classifications/index.jsp?maptype=kpngrp\#maps (accessed on 24 November 2019).

18. Centers for Disease Control and Prevention, Procedure-Associated Module, Surgical Site Infection (SSI) Event. Available online: https://www.cdc.gov/nhsn/pdfs/pscmanual/9pscssicurrent.pdf (accessed on 24 November 2019).

19. Magiorakos, A.P.; Srinivasan, A.; Carey, R.B.; Carmeli, Y.; Falagas, M.E.; Giske, C.G.; Harbarth, S.; Hindler, J.F.; Kahlmeter, G.; Olsson-Liljequist, B.; et al. Multidrug-resistant, extensively drug-resistant and pandrug-resistant bacteria: An international expert proposal for interim standard definitions for acquired resistance. Clin. Microbiol. Infect. 2012, 18, 268-281. [CrossRef]

20. Dudareva, M.; Hotchen, A.J.; Ferguson, J.; Hodgson, S.; Scarborough, M.; Atkins, B.L.; McNally, M.A. The microbiology of chronic osteomyelitis: Changes over ten years. J. Infect. 2019, 79, 189-198. [CrossRef]

21. Tuon, F.F.; Cieslinski, J.; Ono, A.F.M.; Goto, F.L.; Machinski, J.M.; Mantovani, L.K.; Kosop, L.R.; Namba, M.S.; Rocha, J.L. Microbiological profile and susceptibility pattern of surgical site infections related to orthopaedic trauma. Int. Orthop. 2019, 43, 1309-1313. [CrossRef]

22. Ma, X.; Han, S.; Ma, J.; Chen, X.; Bai, W.; Yan, W.; Wang, K. Epidemiology, microbiology and therapeutic consequences of chronic osteomyelitis in northern China: A retrospective analysis of 255 Patients. Sci. Rep. 2018, 8, 14895. [CrossRef]

23. Wang, F.D.; Wang, Y.P.; Chen, C.F.; Chen, H.P. The incidence rate, trend and microbiological aetiology of prosthetic joint infection after total knee arthroplasty: A 13 years' experience from a tertiary medical center in Taiwan. J. Microbiol. Immunol. Infect. 2018, 51, 717-722. [CrossRef]

24. Norton, T.D.; Skeete, F.; Dubrovskaya, Y.; Phillips, M.S.; Bosco, J.D., 3rd; Mehta, S.A. Orthopedic surgical site infections: Analysis of causative bacteria and implications for antibiotic stewardship. Am. J. Orthop. 2014, 43, E89-E92. [PubMed]

25. Tucaliuc, D.; Alexa, O.; Tuchilus, C.G.; Ursu, R.G.; Tucaliuc, E.S.; Iancu, L.S. Retrospective study on the etiological spectrum and antibiotic resistance in infections associated with osteosynthesis materials. Revista Medico-Chirurgicala a Societatii de Medici si Naturalisti din Iasi 2014, 118, 147-153. [PubMed] 
26. Rosteius, T.; Jansen, O.; Fehmer, T.; Baecker, H.; Citak, M.; Schildhauer, T.A.; Gessmann, J. Evaluating the microbial pattern of periprosthetic joint infections of the hip and knee. J. Med. Microbiol. 2018, 67, 1608-1613. [CrossRef] [PubMed]

27. Lenguerrand, E.; Whitehouse, M.R.; Beswick, A.D.; Kunutsor, S.K.; Foguet, P.; Porter, M.; Blom, A.W.; National Joint Registry for England, Wales, Northern Ireland and the Isle of Man. Risk factors associated with revision for prosthetic joint infection following knee replacement: An observational cohort study from England and Wales. Lancet Infect. Dis. 2019, 19, 589-600. [CrossRef]

28. Poultsides, L.A.; Triantafyllopoulos, G.K.; Sakellariou, V.I.; Memtsoudis, S.G.; Sculco, T.P. Infection risk assessment in patients undergoing primary total knee arthroplasty. Int. Orthop. 2018, 42, 87-94. [CrossRef]

29. Kong, L.; Cao, J.; Zhang, Y.; Ding, W.; Shen, Y. Risk factors for periprosthetic joint infection following primary total hip or knee arthroplasty: A meta-analysis. Int. Wound J. 2017, 14, 529-536. [CrossRef]

30. Springer, B.D.; Cahue, S.; Etkin, C.D.; Lewallen, D.G.; McGrory, B.J. Infection burden in total hip and knee arthroplasties: An international registry-based perspective. Arthroplast. Today 2017, 3, 137-140. [CrossRef]

31. Gruskay, J.; Smith, J.; Kepler, C.K.; Radcliff, K.; Harrop, J.; Albert, T.; Vaccaro, A. The seasonality of postoperative infection in spine surgery. J. Neurosurg. Spine 2013, 18, 57-62. [CrossRef]

32. Vickers, M.; Pelecanos, A.; Tran, M.; Eriksson, L.; Assoum, M.; Harris, P.; Jaiprakash, A.; Parkinson, B.; Dulhunty, J.; Crawford, R. Association between higher ambient temperature and orthopaedic infection rates: A systematic review and meta-analysis. ANZ J. Surg. 2019, 89. [CrossRef]

(C) 2020 by the authors. Licensee MDPI, Basel, Switzerland. This article is an open access article distributed under the terms and conditions of the Creative Commons Attribution (CC BY) license (http://creativecommons.org/licenses/by/4.0/). 